\title{
CLLU1 Gene
}

National Cancer Institute

\section{Source}

National Cancer Institute. CLLU1 Gene. NCI Thesaurus. Code C104155.

This gene may be involved in leukemia. 